\title{
Altyazı çevirisi ve eğitimi
}

\section{Ezgi GAGA ${ }^{1}$}

APA: Gaga, E. (2020). Altyazı çevirisi ve eğitimi. RumeliDE Dil ve Edebiyat Araştırmaları Dergisi, (20), 844-854. DOI: 10.2900o/rumelide.792536.

\section{$\ddot{0} \mathbf{z}$}

Görsel-işitsel ürünler teknolojik gelişmeler ve internetin yaygınlaşmasıyla artık tüm dünyada erişilebilir hale gelmiştir. Ürünlerin anlaşılırlığını etkileyen dilsel farklılıklar görsel- işitsel çeviri türleri sayesinde aşılmaktadır. Bu ihtiyacı en hızlı karşılayan çeviri türünün altyazı çevirisi olduğu görülmektedir. Altyazı çevirisi göstergesel, dilsel-metinsel, teknik olmak üzere 3 temel özelliğe sahiptir. Bu özellikler birbirileriyle ilişkisel bir yapı sergileyerek bir bütün oluşturmaktadır. Altyazı çevirisi sürecinde çevirmen görsel-işitsel kanallardan gelen metne okunmak üzere üçüncü görsel bir kanal eklemektedir. Filme dahil olan bu kanalın filmin bütünlüğünü bozmaması ve altyazının görselle uyumlu olması beklenmektedir. Öte yandan zamansal-uzamsal kısıtlar, altyazıya özgü yazım biçimleri ve noktalama işaretlerinin kullanımı, spotlama, eşleme, şablon üretme-kullanma altyazı çevirisinin temel özellikleri çerçevesinde değerlendirilebilir. Dolayısıyla altyazı çevirisi yapabilmek türe özgü bu niteliklerin iyi bilinmesini gerektirmektedir. Şüphesiz, bu alanda yetkinleşmek türe özgü alınacak eğitimle mümkün olacaktır. Günümüzde altyazı çevirisi bir uzmanlık çevirisi olarak kabul edilmekte ve artan talep paralelinde altyazı çevirisi eğitimine yönelik yaklaşımlar geliştirilmektedir. Bu çalışmanın temel amacı çeviribillim literatürü kapsamında altyazı çevirisinin temel özelliklerini incelemek, bu türe yönelik geliştirilen belli başlı eğitim-öğretim modellerini irdelemek ve elde edilen verilerden hareketle altyazı çevirisi derslerinin ne şekilde yapılandığını sorgulamaktır. Bu çalışma altyazı çevirisi eğitimi çerçevesindeki bazı bilimsel çalışmalara bir üst bakış sunarak bu alanda yapılacak araştırmalara zemin hazırlamayı hedeflemektedir. Nitel araştırma yöntemiyle altyazı çevirisi eğitiminin içerik ve uygulamaları altyazının temel göstergesel, dilsel-metinsel ve teknik özellikleri çerçevesinde sınıflandırılmış, bu özelliklerin eğitim yaklaşımları, ders içeriği ve öğretim yöntemleri, materyalleri, ölçme ve değerlendirme biçimlerini şekillendirdiği görülmüştür. Araştırmanın sonunda altyazı çevirisi eğitiminin birbirini takip eden ve tamamlayan becerilerin edinimi biçiminde gerçekleştiği görülmektedir.

Anahtar kelimeler: Altyazı, altyazı çevirisi, altyazı çevirisi eğitimi

\section{Subtitle translation and education}

\begin{abstract}
Audiovisual products have now become accessible worldwide with the advancement of technology and spread of intenet. The linguistic differences affecting the intelligibility of the products are overcome thanks to the types of audiovisual translations. It is seen that subtitle translation is the type of translation that meets the need the fastest. Subtitle translation has 3 basic features: semiotic, linguistic-textual, technical. These features form a whole by displaying a relational structure with each other. During the subtitle translation process, the translator adds a third visual channel to the
\end{abstract}

1 Dr. Öğr. Üyesi, Atlas Üniversitesi, İnsan ve Toplumbilimleri Fakültesi, Mütercim Tercümanlı Bölümü (İngilizce) (İstanbul, Türkiye), ezgi_keskin@hotmail.com, ORCID ID: oooo-0001-8985-3517 [Makale kayıt tarihi: 06.08.2020kabul tarihi: 20.09.2020; DOI: 10.29000/rumelide.792536] 
text to be read through the audiovisual channels. It is expected that this channel, which is included later, should not harm the integrity of the film and the subtitle should be compatible with the visual. On the other hand, temporal and spatial constraints, subtitle-specific spelling styles and the use of punctuation marks can be evaluated within the framework of the basic features of the subtitle translation. Therefore, these specific features regarding subtitle translation should be well-known for translating process. Without doubt, through specific training, it is possible to become competent in this field. Today, subtitle translation is accepted as a specialised translation. With the increasing demands, new approaches on subtitle translation education are being developed. The main purpose of this study is to examine the basic features of subtitle translation within the scope of translation studies, to examine the some education models developed for this type and to question how the subtitle translation courses are structured based on the data obtained. This study also aims to lay the groundwork for research to be conducted in this area by presenting an overview of some scientific studies within the framework of subtitle translation education. With the qualitative research method, the content and applications of subtitle translation education were classified within the basic semiotic, linguistic-textual and technical features of the subtitle, and it was observed that these features shaped educational approaches, course content and teaching methods, course materials, measurement and evaluation styles. In this research, it is understood that subtitle education takes place in the form of acquisition of skills which follow and complement each other.

Keywords: Subtitle, subtitle translation, subtitle translation education

\section{Giriş}

Teknolojinin gelişmesi ve iletişim araçlarının artmasıyla görsel-işitsel materyaller hızla küresel boyuta taşınmaktadır. Ürünlerin anlaşılırlığını etkileyen dilsel farklılıklar görsel işitsel çeviri türleri ile aşılmaktadır. Bu ihtiyacı en hızlı biçimde karşılayan çeviri türünün altyazı çevirisi olduğu söylenebilir. Altyazı, istatistiki açıdan veri olmasa da görsel-işitsel çeviri türleri içinde en çok tercih edilen çeviri yöntemi olarak kabul edilmektedir (Diaz-Cintas, 2013, 119-132).

Altyazı çevirisi, göstergesel, dilsel-metinsel, teknik olmak üzere üç temel özellik çerçevesinde biçimlenir. Bu özellikler birbirileriyle ilişkisel bir yapı içindedir. Altyazı çevirmeni göstergesel boyutta görsel-işitsel kanallardan gelen metne yazılı üçüncü görsel bir kanal eklemektedir. Bu kanalın filmin göstergesel bütünlüğ̈nü bozmaması ve görselle uyumlu olması gerekmektedir. Öte yandan, dilsel metinsel özellikler içinde zamansal-uzamsal kısıtlar, altyazıya özgü yazım biçimleri ve noktalama işaretlerinin kullanımı ve teknik özellikler kapsamında ise spotlama, eşleme, şablon üretme/kullanma altyazı çevirisinin temel nitelikleri içinde yer alır. Altyazı çevirisi bu özelliklerin iyi bilinmesini gerektirmekte ve bu alanda yetkinleşmek ancak türe özgü alınacak eğitimle mümkün olmaktadır. Günümüzde altyazı çevirisi bir uzmanlık çevirisi olarak kabul görmektedir. Hızla artan ihtiyaç, altyazı çevirisi eğitimine yönelik yaklaşımları beraberinde getirmiştir. Bu çalışmada altyazı çevirisinin temel özellikleri incelenmekte, altyazı çevirisi eğitimine yönelik eğitim-öğretim yaklaşımları ele alınarak altyazı çevirisi derslerinin ne şekilde yapılandığı incelenmektedir. Bu bağlamda, altyazı çevirisi ve eğitimine yönelik kaynaklar taranarak altyazı eğitiminin uygulama biçimleri hakkında değerlendirmelere yer verilecek ve bir üst bakış sunulacaktır. Nitel araştırma yöntemiyle altyazının temel özellikleri paralelinde biçimlenen altyazı çevirisi eğitiminin genel çerçevesi betimlenecektir. Bu çalışma ile ayrıca geliştirilmesi gereken noktalar tespit edilerek gelecek araştırmalara katkı sağlama hedeflenmektedir. 


\section{Altyazı süreci}

İlk altyazı yazılımı 1970'lerde piyasaya sürülmüş̧ür. Altyazı işlemleri dönem itibarıyla teknik bir donanım gerektirdiği bilinmektedir. Çeviri yapabilmek için bir bilgisayar, video kaydını oynatmak için video oynatıcı ve izlemek içinse TV monitörüne ihtiyaç vardı. Bazı çevirmenler, diyalogların başlama ve bitiş sürelerini belirlerken kronometre kullanıyorlardı (Diaz-Cintas, 2013: 119-132). Çevirmenler, çoğunlukla programın yazılı metninden çeviri yapmaktaydılar. Altyazılar elle yazılırdı ve çevirmenlerin bu ekipmanları kullanacak teknik bilgiye sahip olmaları beklenmezdi. Çevirmenler yalnızca çeviriden sorumluydu (Carrol, 2004).

Altyazı işleminin teknik boyutu film teknisyeninin sorumluluğundaydı. Film diyalogları film teknisyenleri tarafından eşlenirdi. Konuşmalarının başladığı ve bittiği yerler teknisyen tarafından işaretlenirdi. Altyazıyı ekran formatına uygun yazabilen özel bir altyazı programı kullanılmaktaydı. İlk altyazı yazılımının 1970’lerde piyasaya sürüldüğü bilinmektedir (Diaz-Cintas, 2013: 119-132).

1990'larda kişisel bilgisayarların yaygınlaşmasıyla altyazıların hazırlanma süreci tamamen değişmiş ve dil uzmanlığı çerçevesinde altyazı çevirmenliği mesleği yeniden tanımlanmıştır (Carrol, 2004). 1990'lı yıllarda profesyonel altyazı programlarının sayıca az, pahalı ve erişilmesi zor olması altyazı çevirmenlerini internetin sunduğu imkanları kullanmaya yönlendirdi. Bu bağlamda bu işi yapan profesyoneller kendi altyazı oluşturma çözümlerini ürettiler. İnternet ortamına sürülen altyazı programları indirilerek altyazı işlemi gerçekleştirebilmekteydi. İnternette en çok bilinen ve tercih edilen ücretsiz altyazı programları arasında Aegisub, DivxLand Subtitler, Gnome Subtitles, Jacosub, Subtitle Creator, Subtitle Workshop yer almaktadır (Diaz-Cintas, 2013, 119-132).

Öte yandan, profesyonel altyazı çevirisi programları, kısa zamanda, hızlı çeviri yapabilmek üzere tasarlanmıştır. Altyazıların zaman kodlarının belirlenmesi için bazı programlar geliştirilerek altyazıların eşleme süreci basitleştirilmiş oldu. Altyazı çevirisini hızlandıran bir diğer teknoloji "ses tanıma² ve eşleme teknolojisi3"dir. Görsel işitsel ürünlerin yazılı metni programa aktarılmasının ardından dahili konuşma tanıma sistemi ses ve görüntüyü eşlemekte ve otomatik bir zaman kodu oluşturmaktadır. Google ve Youtube tabanlı videolarda bu sistem kullanılmaktadır (Diaz-Cintas, 2013, 119-132).

Özetle, günümüzde altyazı çevirmenin çeviri yapması için gerekenler: zaman kodu içeren görsel-işitsel metnin kopyası, diyalog listesi, görsel bilgiler, metin görsel-işitsel ürün film ise çevirmene özel notlar içeren post-prodüksiyon senaryosudur. Eşleme sürecinde, diyaloglar zaman kodlu birimlere bölünür. Ardından her diyalog parçası zaman-yer kısıtları ve biçim kılavuzlarına göre çevrilir. Bu süreç, altyazıların dijital olarak sorumlu kişiye verilmesiyle son bulur. Gelişen teknolojiyle görsel-işitsel metinlerin dijital formatlar halinde kolayca paylaşılması ve altyazı için özel yazılımların tasarlanması, bu süreçte büyük değişiklikler meydana getirmiştir. Tüm profosyenel çevirmenler bu teknik imkânlara sahip olmasa da, artık çevirmen ortalama bir bilgisayarla tüm alt yazılama işlemini tek başına gerçekleştirebilmektedir (Perez 2008: 15). 


\section{Altyazının temel özellikleri}

Görsel-işitsel çeviri türleri kapsamında altyazı çevirisinin temel özellikleri göstergesel, dilsel-metinsel ve teknik özellikler olmak üzere 3 boyutta değerlendirebilir. Bu özellikler bir yapı içerisinde birbiriyle ilişkisel bir bütünlük sergilemektedir.

\subsection{Göstergesel özellikler}

Altyazı çevirisinde kaynak metin, görsel ve işitsel göstergelerin bir araya gelmesinden oluşan çok göstergeli karma bir metin niteliği taşır. Anlamı, dil, görüntü, müzik, renk ve perspektif gibi kodların tamamı oluşturur ve bir bütün olarak algılanır. Anlamı oluşturan bu çok sayıda gösterge, izleyiciye çeşitli kanallardan aynı anda gelir. Alman dilbilimci ve çeviribilimci Katharina Reiss, (1971, s.24-52) Karl Bühler' in dilin 3'lü işlevine ${ }^{4}$ dayanarak geliştirdiği Organon Modeli’nde metin sınıflandırması ${ }^{5}$ yapmış; görsel-işitsel metinleri işitsel-araçlı metinler (audiomedial texts ) olarak tanımlamıştır. Bir başka çalışmasında Reiss, işitsel-araçlı metinleri çeşitli açılardan ele alarak çok araçlı metinler (multimedial) adıyla güncellemiştir. Bu kapsamda görsel-işitsel metinler yazılı ve sözlü öğelerin yanı sıra görüntü, müzik, görsel efektler, jest, mimik, kamera, ışık kullanımı gibi birçok görsel ve işitsel göstergeden oluşmakta bu bağlamda içerik olarak bilgilendirici, anlatımsal ve işlemsel yapıda diğer tüm metin türlerini içeren hiper-metin (hyper-text) özelliği göstermektedir (2004, s. 164-165).

Görsel-işitsel çeviri aracılığıyla çok kipli (multimodal) ve çok kanallı (multimedial) metinler erek izleyici için bir dilden ve/ya kültürden diğerine aktarılarak anlaşllır hale getirilmektedir (Luyken vd, 1991, s. 11). Bu iletişimsel süreç, görsel-işitsel çeviri aracıllğıyla gerçekleşmektedir.

Altyazı çevirisi sırasında çevirmen görsel-işitsel kanallardan gelen metne okunmak üzere üçüncü görsel bir kanal ekler. Bu yeni kanalın, metnin göstergesel yapısıyla uyumlu olması gereklidir (Diaz-Cintas, Remael 2014, 45; Okyayuz, 2016, 79). Altyazı çevirmeni, çevirisini yapacağı görsel-işitsel metni çözümleyecek yetkinlikte olmalıdır. Altyazı çevirisinde konuşmalar kaynak metni oluştursa da metin diğer kanallardan gelen diğer tüm öğelerle birlikte anlam kazanır (Diaz-Cintas; Remael 2014, 46-47). Özellikle belli bir kurguya sahip metinlerde her bir sahne, diyalog, kamera hareketi, ses vb. belli bir amaca sahiptir, dolayısıyla tüm bu göstergeler bir bütün olarak ele alarak çeviri yapılmalıdır. Çevirmen metni analiz ederek hangi göstergelerin önem taşıdığını ve hangilerinin ek bilgi olduğunu iyi tespit edebilmeli ve altyazının zamansal-uzamsal kısıtları doğrultusunda çeviri kararları vermelidir (Okyayuz, 2016, 82).

\subsection{Dilsel-metinsel özellikler}

Zamansal kısıtlar: Altyazı çevirisinin dilsel-metinsel boyutunu uzamsal ve zamansal kısıtlar belirler. İnsanların konuşma hızı, okuma hızından daha hızlıdır. Dolayısıyla izleyiciler, okuduklarını konuşmaya göre daha fazla sürede anlarlar. Altyazı çevirisinde izleyiciler ekranda izleyip dinlediklerini okuduklarıyla birleştirmek zorundadır ve bunun için belirli bir süre gerekir (Diaz-Cintas; Remael 2014). Bir televizyon seyircisinin ortalama saniyede 2-3 kelime okuduğu tespit edilmiştir (Karamitroglou, 1998, 1). Okuma hızları ülkelere ve şirketlere göre farklılık gösterse de genellikle dünya çapında 'altı saniye'

temsil, ifade , çekicilik (representation, expression, appeal)

Reiss'a göre çeviriler metinlerin ağırlıklı işlevlerine göre yapılmalıdır. Bu sınıflama kapsamında bilgi ağırııklı, içerik odaklı metinler: bilgilendirici (informative texts); yazınsal bir dil kullanımın öne çıtığı biçim odaklı metinler: anlatımsal (expressive texts); hedef kitleyi belli bir amaç doğrultusunda yönlendirme amacını taşıyan çağrı odaklı metinler: işlemsel (operative texts) ve radyo, televizyon ve sinema gibi kitle iletişim araçlarında kullanılan metinleri işitsel-araçlı metinler (audiomedial texts )olarak tanımlamıştır (1971, s. 24-52) 
kuralı uygulanmaktadır. Yayınlanan programa göre her bir satır, ekranda üç saniye kalmaktadır. Bu süre iki satırlık altyazı için en fazla beş ile altı saniye; üç satırlık altyazı içinse sekiz saniyedir (Linde; Kay, 2016, 7). Altyazıların ekranda çok kısa kalması izleyicinin algılamasını etkilerken; uzun kalması ise altyazının tekrar okunmasına neden olmaktadır.

Uzamsal kısıtlar: Altyazılar, uzamsal açıdan 30 ya da 40 karakterden oluşan en fazla 2 (nadiren 3) satırlık yer kaplamaktadır (O'Connell, 2007, 129). Bu satırlara ne kadar yazı yazılacağı ekrandaki kişilerin konuşma hızı ve izleyicinin altyazı okuma hızına bağlıdır (Diaz Cintas; Remael 2014, 145). Öte yandan, altyazı çevirisi kaynak metne yeni görsel bir kanal eklentisi olarak düşünüldüğünde, ekranda çok yer kaplaması özellikle kaynak dili bilen izleyicide olumsuz bir tepki yaratabilir (Diaz Cintas; Remael 2014, 87). Kısacası, zamansal ve uzamsal kısıtlardan dolayı tüm konuşulanları altyazıda vermenin imkanı yoktur. Bu durumda altyazı çevirmeni altyazı çevirisinde dilsel ve metinsel değişiklikler yapar. Metinsel kısaltmalarda metin parçaları ya tamamen atılır (tam kısaltma) ya özetlenir veya yeniden yazılır (kısmi kısaltma) (Diaz Cintas; Remael 2014, 146). Çevirmen karar verirken bilgi aktarımı açısından en gerekli öğeleri seçer ve diğer öğelerin göreli önemlerini gözeterek çevirisini biçimlendirir (Okyayuz, 2016, 88). İfadelerin öneminin tespit edebilmesi için görsel-işitselin tamamıyla izlenmesi ve çıkarması planlanan ifadelerin filmin anlaşılırlığına etki etmeyeceğinden emin olmalıdır.

Yazım ve noktalama: Altyazıların izleyiciler tarafından rahatça ve kısa sürede anlaşılması için dilbilgisi kurallarına uygun ve söz dizimsel açıdan kurallı olması gerekir. Ayrıca, yazım ve noktalama kurallarına uyulması altyazıların daha rahat anlaşılmasını sağlamaktadır. Altyazı, yazılı metin türü kapsamında bulunduğu için tüm standart yazım ve noktalama kurallarıyla birlikte altyazıya özgü belirli yazım ve noktalama geleneklerine dayanarak oluşturulmalıdır (Diaz Cintas, 2008, 100). Altyazı hizmeti sunan şirketlerin çoğu kendi stil kılavuzlarını oluştursa da bazı yaygın kullanımlar standartlaşmıştır. Altyazı çevirisinde bazı noktalama işaretleri ve yazım biçimleri standart kullanımların yanı sıra bazı özel anlamlar taşır. Bu kullanımlar altyazıların parçalı yapısının, izleyici tarafından daha iyi anlaşılmasını sağlamaktadır. Bazı araştırmacılar altyazı çevirisinde noktalama ve yazımda standartlaşmış kullanımları derleyen çalışmalar yapmıştır (bkz.Karamitroglou, 1998; Diaz Cintas ve Remael 2007, 102-119).

\subsection{Teknik özellikler}

Altyazıların teknik özellikleri arasında spotlama, eşleme (senkronlama), şablon üretme /kullanma yer alır.

Spotlama: Konuşmaların başlangıç ve bitiş sürelerini belirlemeye spotlama denir. Orijinal diyaloglar spotlama yapılarak parçalara ayrılır ve altyazı için hazır hale gelir. Bu işlem esnasında konuşma ile altyazı eşzamanlı başlamalı ve bitmelidiır. Konuşmanın başladığı ve bittiği süre 8 basamaklı bir zaman koduyla ifade edilir.

$02: 40: 12: 34$

02 görsel işitsel metnin saatini, 40 dakikayı, 12 saniyeyi, 34 ise film karesini gösterir. Zaman kodu sayesinde spotlama işlemi kolaylaşır. Konuşmaların giriş ve çıkış süresi belirlendikten sonra ekranda ne kadar kalacağı hesaplanabilmektedir. Spotlama sırasında altyazı, sahnenin değiştiği yerlerde (shot change) verilmemelidir. Altyazının sahne bitmeden ekrandan gitmesi gerekir. Yeni altyazı ekrana sahne değiştikten sonra gelmelidir. Bu durum, izleyicinin refleksif göz hareketiyle açıklanmaktadır. Sahne 
değişiminde altyazı ekranda kaldığı takdirde izleyici altyazının değiştiğini düşünecek aynı altyazıyı tekrardan okuma eğilimine girecektir (Diaz Cintas ve Remael, 2014, 91).

Çeviriyi zorlayan bir başka durum bir sahnede birçok kişinin aynı anda konuşmasıdır. Konuşmaların giriş-çıkış zamanlarında çakışma olabilir. Böyle anlarda hangi bilginin çevrileceği, hangi bilginin çıkartılacağı çevirmenin kararına bağlıdır. Ayrıca, zamanlama izleyicinin kimin ne söylediğini anlayacağı biçimde yapılmalıdır. Altyazının ekranda konumlanmasının da önemi vardır. Altyazıların kaç satırla verileceği estetik kaygılarla birlikte okunabilirliğe, sözdizimsel ve anlamsal açıdan algılanmasına, konuşmanın tonlanmasına bağlıdır (Diaz Cintas ve Remael, 2014, 86).

Eşleme (Senkronlama): Altyazı çevirisinde altyazı ve ses arasındaki senkron, izleyicinin altyazının kalitesini olumlu veya olumsuz algılamasına etki eder. Altyazılar, çok erken ya da geç ekrana geldiğinde veya işitsel öğeden bağımsız ekrandan ayrıldığında, izleyiciyi rahatsız edebilir. Bu durum, görsel-işitsel ürünün izleme zevkini azaltabilmekte çevirinin başarısına gölge düşürebilmektedir. Dolayısıyla başarılı eşleme, metin içi tutarlılı̆̆ güçlendirmekte ve izleyicinin kimin ne söylediğini rahatça takip etmesini sağlamaktadır. Bazı altyazı programları ses tanıma özelliği sayesinde konuşmanın başlama ve bitiş zamanları belirlemekte ve altyazının ekranda ne kadar kalacağını kolayca hesaplamaktadır. İzleyicinin yeni altyazıyı algılayabilmesi için altyazıların arasına ortalama 2 ile 4 kare (frame) kadar bir zaman aralığı bırakılmaktadır (Diaz Cintas, 2008. 95).

Şablonlar: Çeviri şablonlarının ortaya çıkış amacı, kaynak kültür ürününün erek kültüre uzak olduğu durumlarda ara dil üzerinden çeviri yapılarak ara metin oluşturmadır. Ancak şablonlar ticari açıdan zaman ve para tasarrufu sağladığı için, uygulamada ara dilin erek kültüre yakınlığının düşünüldüğü kadar önemli olmadığı görülmüştür (Gottlieb, 2001, 32).

Şablon kullanım süreci, altyazı çevirisini başlangıç dönemine geri getirdiği söylenebilir. Tıpkı ilk zamanlarda olduğu gibi çeviri iki aşamalı bir süreçte yapılmaya başlanmıştır. Özellikle Hollywood merkezli yapım şirketlerinin talepleri, görsel-işitsel metnin ana dili İngilizce olan kişiler tarafından spotlanması (zaman kodlarına ayırma), ardından bu şablonun diğer dillere çevrilmek üzere kaynak metin olarak paylaşılması yönündeydi (Georgakopoulou, 2006).

Çeviri şablonlarının ortaya çıkışı şüphesiz altyazı çevirmenliği meslek tanımını dönüştürmüştür. Çevirinin teknik boyutunu daha kolay yönetmek, ticari açıdan maliyet ve süreyi azaltmak isteyen şirketler özellikle şablonla altyazı çevirisi yaptırmayı tercih etmektedirler. Şablon kullanımı işin spotlama, eşleme, altyazı yerleştirme gibi teknik işlemlerinde çevirmenlerin rollerini azalmış, çevirmenleri çevirinin yalnızca dilsel ve anlamsal boyutuna yöneltmiştir. Neticede, piyasada şablon çeviriyi üreten çevirmenler ve şablon üzerinden çeviri yapan çevirmenler olmak üzere iki işi tanımı ortaya çıkmıştır. Doğal olarak işverenler bu iki hizmet için ayrı ücretlendirme yapmaktadır (Nikolić, 193194). Dolayısıyla her iki alanda da uzman olan altyazı çevirmenlerinin sektörde ön plana çıktığı söylenebilir.

Özetle, altyazı çevirisi, göstergesel, dilsel-metinsel ve teknik olmak üzere 3 temel başlıkta incelenmektedir. Altyazı çevirmeni çok göstergeli görsel-işitsel kaynak metni iyi çözümlemeli, zamansal ve uzamsal kısıtlar dahilinde gerekli kısaltmaları yapabilmeli, teknik boyutta çeviri öncesinde spotlama sonrasında eşleme uygulamalarında yetkin olmalıdır. Yetkinlik şüphesiz uzmanlık eğitimi ile mümkün olacaktır. Bu eğitim kapsamında söz konusu alanlarda çevirmen adaylarının edineceği beceriler verilecek eğitimin içeriğini oluşturacağı söylenebilir. 


\section{Altyazı çevirisi eğitimi}

Altyazı çevirisi yapabilmek altyazıya özgü göstergesel, dilsel-metinsel ve teknik özelliklerle ilgili becerileri edinmeyi gerektirmektedir. Bu becerilerin öğretimi üzerine birçok araştırma yapılmakta ve çeşitli yöntem önerileri ileri sürülmektedir. Bu bölümde altyazı çevirisi eğitimine yönelik bazı yaklaşımlara yer verilecektir. Altyazı çevirisi eğitiminin göstergesel, dilsel-metinsel ve teknik özellikleri çerçevesinde nasıl şekillendiği sorgulanacaktır. Nitel araştırma yöntemiyle altyazı çevirisi eğitiminin içerik ve uygulamalarına altyazının göstergesel, dilsel-metinsel ve teknik özellikleri çerçevesinden bakılacak bu özelliklerin ne ölçüde öğretim yöntemlerini, ders materyallerini, ölçme ve değerlendirme biçimlerini şekilledirdiği incelenecektir.

\subsection{Ders içeriği ve öğretim yöntemleri}

Altyazı çevirisi eğitiminde göstergesel, dilsel-metinsel ve teknik alanlarda bilgi ve becerilerin edinilmesi esastır. Dolayısıyla içerik oluştururken ve eğitim-öğretim yaklaşımı belirlerken öğrencilere söz konusu yetkinliklerin kazandırılması hedeflenir. Bu bağlamda görsel-işitsel çeviri alanında birçok araştırmaya sahip Jorge Diaz-Cintas, altyazı çevirisinde temel bilgi ve becerilerle ilintili bir eğitim modeli önermiştir. $\mathrm{Bu}$ modelde dersin giriş, teknik, dilsel ve profesyonel boyutlarda tasarlandığı görülmektedir. Modelin giriş bölümünde görsel-işitsel çeviri alanına genel bir bakış sergilenmekte ve altyazının türler arasında aldığ konum incelenmektedir. Teknik ve dilsel boyutlarda altyazı çevirisinin göstergesel, dilsel-metinsel ve teknik özelliklerine odaklanıldığı görülmektedir. Profesyonel boyutta ise altyazı çevirmenliği mesleğine dair kazanımlar ele alınmaktadır (2008, 92). Diaz Cintas'ın modeline benzer bir diğer yaklaşım Mümtaz Kaya ve Şirin Okyayuz'un altyazı çevirisi eğitimi modelinde görülmektedir. 5 bileşenli modelde ilk bileşende, kuramsal ve bilişsel boyutta görsel-işitsel çeviri türleri ve altyazı hakkında bir bakış açısı oluşturulurken 2. bileşende altyazı çevirisine özgü teknik bilgi sunulmaktadır. 3. bileşende dilsel-metinsel kurallar ve altyazı çevirisi yöntemlerinin edinimi, 4. bileşende çeviri ürünü standartlara göre düzeltme ve ürünü gösterime hazırlama, 5 . son bileşende çeviri sürecine dair öz değerlendirme yetkinliklerini kazandırma hedeflenmektedir. Söz konusu ders tasarımları birçok açıdan benzerlik taşımaktadır.

Diaz Cintas ve Kaya-Okyayuz modellerinin ilk bileşenlerinin/boyutlarının genel çerçevesi aynıdır. Bu bölümde görsel-işitsel çeviri hakkında temel bilgiler verildikten sonra altyazı çevirisinin diğer türler içindeki konumu ve kendine özgü kısıtlar ele alınmalıdır. Konular çok sayıda örnekle desteklenerek öğrenciyi düşünmeye yönlendirmeli, öğrencinin kuramsal ve bilişsel açıdan bu alanda temel oluşturması hedeflenmelidir. Kademeli olarak gözlem ve teoriden uygulamaya geçiş planlanmalıdır (Okyayuz, Kaya 2017, 15; Cintas, 2008, 92). Öte yandan bu kısmı çok uzun tutmamak gerekir. Bunun için tümevarım yöntemini öneren Diaz-Cintas öğrencilerin dersin başından itibaren uygulamaya geçmelerinin yerinde olacağını, kendi öğrenim deneyimlerinin teorik bilgiyi pekiştireceğini ve performanslarını arttıracağını ifade etmektedir. Öğrenciler işlemsel bilgiye bu yolla daha hızlı geçeceklerdir. Her iki modelin ikinci aşaması teknik bilginin aktarımıdır. Öğrencilere altyazı programlarının temel çalışma prensipleri gösterilmeli ve çok sayıda uygulamayla aktarım desteklenmelidir. Piyasadaki birçok altyazı programı benzer özelliğe sahiptir dolayısıyla eğitim amacıyla çevrimiçi ve ücrete tabi olmayan bir altyazı programı seçilerek sınıfta kullanılabilir (Kaya, Okyayuz 2017, 15). Öğrencilerin altyazı programlarının temel mantığını anlamaları yeterli olacaktır. Altyazı hizmeti veren bazı şirketler ${ }^{6}$ kendi yazılımlarının deneme sürümlerinin indirilmesine izin vermektedir. Bir diğer alternatif JacoSub ya da Subtitle Workshop gibi ücretsiz altyazı yazılımlarıdır. Her iki seçenek eğitim kurumlarına maliyet yaratmadan öğrencilerin

bkz. FAB, SPOT, WinCaps 
altyazı becerilerini geliştirmelerine olanak sağlamaktadır (Diaz Cintas, 2008, 95). Şüphesiz değisşen teknolojiyle altyazı yazılımları sürekli güncellenmektedir. Dolayısıyla sınıf içi etkinlik olarak öğrencilerden gruplar halinde altyazı programları ile ilgili araştırma ve sunum yapmaları istenebilir. $\mathrm{Bu}$ sayede öğrenciler ders kapsamında birçok programı tanıma firsatı elde edebileceklerdir (Kaya, Okyayuz, 2017, 15). Sınıfta yapılan alıştırmalar gerçek altyazı işlerine paralel olmalıdır. Yazılımı kullanmaya geçmeden yazılımın temel nitelikleriyle derse başlamalı, aşamalı olarak öğrencinin teknik bilgisi uygulamayla pekiştirilmelidir. Bu aşamada öğrencilere zaman kodu (timecode) açıklanabilir, spotlama ve eşlemenin nasıl yapılacağı gösterilebilir ve çeviri şablonları üzerinden alıştırmalar yaptırılabilir (Diaz Cintas, 2008, 95). Öğrenciler çeviri şablonunu kullanarak aynı zaman ve uzam kısıtları içinde altyazı üretebileceklerdir. Eğitmenler tartışma merkezli öğrenme ortamı yaratarak öğrencileri çeviri kararlarını tartışmaya yönlendirebilir (Diaz Cintas, 2008, 99).

Dersin dilsel boyutunda öğrencilere altyazı çevirisine özgü yazım kuralları, metin konumlandırma, altyazıların ekranda kalış süreleri vb. gibi özellikler ve metni kısaltma, çeviri sorunlarını tespit etme, bunlara yönelik düşünme ve yöntem geliştirme gibi altyazı çevirisinin kısıtlarıyla ilişkili temel beceriler kazandırmaya çalışılmaktadır. Ancak bu becerilerin aynı ders saatinde verilmesi önerilmez. Bu beceriler birbirini takip eden derslerde tamamlayıcı biçimde verildiğinde verimli olacaktır (Okyayuz, Kaya, 2017, 16).

Diaz Cintas'ın dilsel boyutta değerlendirdiği çeviri ürünü kalite standartlarına uygun hale getirme ve öz değerlendirme becerileri Kaya-Okyayuz modelinin dördüncü bileşeni ve tamamlayıcı olarak 5 . bileşeninde yer alır. Bu aşamada eğitmen, hataları, eksikleri gösterme ve düzeltmek için uygulamalar yapmalıdır. Son aşamada dersin başından itibaren sunulan teorik bilgiler, tartışmalar, çeviri deneyimleri ve süreçleri irdelenerek öğrencilerin öz değerlendirme yetkinliği edinmeleri beklenir. Bu bağlamda öğrencilerden çeviri raporu istenmesi çeviri ürünlerine ilişkin çok boyutlu düşünmeleri, altyazı uygulanmasının ilke ve normlarını ne ölçüde öğrendiklerini gözleme açısından faydalı olacaktır (Okyayuz, Kaya, 2017, 16).

Altyazı çevirisi eğitimi çerçevesinde altyazı piyasasının tanıtımı dersin profesyonel boyutunu oluşturur. Altyazı çevirisi sürecine çevirmenle birlikte birçok profesyonel katkı sağlamaktadır. Dolayısıyla öğrencilerin çeviri işinin alımından teslimine kadar geçen her aşamadaki aktif görev alanlarını bilmeli ve çalışma koşullarını öğrenmelidir; neticede piyasaya ne kadar donanımlı girerlerse iş bulma olasılıkları o kadar artacaktır (Diaz Cintas, 2001, 29-30). Dersin bu bileşenini güçlendirmek için altyazı piyasasından konuk konuşmacılar çağırmak veya altyazı hizmeti sunan şirketlere ziyaretler yapmak oldukça faydalı olacaktır (Diaz Cintas, 2008, 97).

Diaz-Cintas metin türünün çoklu göstergesel yapısından dolayı eğitim modelinde göstergesel (semiotic) boyutu ele alır. Bu aşamada öğrencilere çevirdikleri metnin yalnızca diyalogtan oluşmadığını, anlamı farklı kanallardan gelen tüm göstergelerin oluşturduğu fark ettirilmelidir. Dolayısıyla öğrencilerin ince dilsel nüansları görebilmesini sağlayacak, göstergeleri çözümleyebilecek beceriler öğretilmelidir (Diaz Cintas, 2008, 80).

\subsection{Ders materyalleri ve ölçme değerlendirme}

Altyazı çevirisi dersinde kullanılacak materyaller orijinal görsel-işitsel metinler olmalıdır (Diaz Cintas, 2008, 92). Ders kapsamında yalnızca sinema ve film değil, söyleşiler, DVD röportajlar, şirket videoları, tanıtım videoları gibi görsel-işitsel metinler seçilerek farklı terminolojiler üzerinde çalışılabilir. Seçilen 
metinler tartışmaya açık, farklı çeviri yöntemleri kullanmaya uygun olmalıdır. Ayrıca kültüre özgü deyişler, argo ifadeler, örtük ve tabu deyişler, kelime oyunları, küfürler, espriler ve şarkıların bulunduğu görsel-işitsel metinler öğrencilerin farklı çeviri zorluklarını deneyimlemeleri için oldukça faydalı olacaktır (Diaz Cintas, 2008, 101). Ayrıca görsel-işitsel metinlerin çoklu-göstergesel bütünlüğü göz önüne alınarak, bütünden kesilmiş, bağlamından koparılmış metinlerle, metnin bütününe erişimin olmadığı materyaller eğitim amaçlı kullanılmamalıdır (Kruger, 2008, 80).

Altyazı eğitiminde ölçme ve değerlendirme yöntemlerine bakıldığında bütüncül yaklaşımlar öne çlkmaktadır. Akademik ve profesyonel değerlendirme birbirinden farklıdır. Profesyonel değerlendirmede tek bir hata dahi kabul edilmezken akademik değerlendirmede doğruya yakın tercihler kabul görebilir. Şüphesiz, akademik değerlendirme biçimi profesyonel hayatta uygulanmamaktadır; ancak üniversite eğitiminde süreç odaklılığın esas olduğu öğrencilerin hatalarından öğrendiği öğretim yöntemleri uygulanabilmekte; bu sayede öğrencilerde farkındalık kazandırılmak istenmektedir (Kruger , 2008, 81).

Altyazı çevirisi dilsel (içerik ve dil) ve teknik beceriler ölçülmektedir (Diaz Cintas, 2008; Wietrzny, Tymczyńska, 2015). Diaz-Cintas (2001) dilsel boyutta, gerekli tüm bilgilerin aktarımı (bilgilendirici), mesajın doğru şekilde verilmesi (anlamsal), sözlü dilden yazılı dile geçişte doğallık (iletişimsel), altyazılar arasında tutarlı bölümleme ve yazım noktalama kurallarına uygunluk kriterine; teknik boyutta ise yeterli okuma süresi, eşleme, altyazılar arasındaki yeterli süre, altyazının ekranda yerleşimi kriterlerine göre değerlendirmektedir.

Wietrzny ve Tymczyńska, Diaz-Cintas'a paralel dilsel ve teknik açından değerlendirme yapar (2015, 347348). Dilsel boyutta içerik, çeviri yöntemi ve dilsel eşdeğerlikler tespit edilir. Çeviri öncesinde öğrencinin filmde önemli olan bilgileri belirleyip kısaltma yapması gereklidir. Yapılacak çıkarmalar, filmin anlamını etkilememelidir. Çeviri yöntemi programın türüne, ritmine, seyircilerin okuma hızına göre seçilmelidir. Altyazılar bölümlenirken anlamsal bütünlük ve metin içi tutarlılık dikkate alınmalıdır. Ayrıca yazım, imla ve dilbilgisi kurallarına uygunluk değerlendirilmelidir. Teknik açıdan ise formatlama ve senkronizasyon ölçülmelidir. Öğrenci eşleme ve formatlama sırasında kabul görmüşs stil klavuzlarına ve teknik standartlara uygun altyazı oluşturmalıdır.

Wietrzny ve Tymczyńska’nın notlandırma ölçütünde öğrenci performansları 40 puan üzerinden eksiltmeler yapılarak notlandırılmaktadır. Öğrenciler, yazım ve noktalama yanlışı (-o,25), anlamı çok bozmayan hatalar (-0,5), anlamı bozan ciddi hatalar (-1), anlamı çok ciddi bozan hatalar (-2) kriterlerine göre değerlendirilmektedir. Notlandırma ölçütü olarak 40-35 çok iyi, 34-29 iyi, 28-24 yeterli, 23-0 başarısız kabul edilmektedir. Notlandırmayı etkileyen bir diğer faktör öğrencilerin çeviri kararlarını gerekçelendirdikleri çeviri raporlarıdır. Ayrıca araştırmacılar çeviri sorunlarına yönelik verdikleri yaratıcı çeviri kararlarına verilecek ekstra puanlar motivasyonu arttırmada oldukça etkilidir (2015).

\section{Sonuç}

Özetle, yukarıdaki çalışmalar çerçevesinde, altyazı çevirisi eğitiminin içeriği, eğitim-öğretim teknikleri, materyalleri, ölçme ve değerlendirme yöntemlerinin altyazının dilsel-metinsel, göstergesel ve teknik özellikleri çerçevesinde şekillendiği görülmektedir. Altyazı çevirisinin niteliklerini temele alan bu yaklaşımlar öğrencilere altyazı çevirisinin doğasına yönelik beceriler kazandırmayı hedeflemektedir. Söz konusu eğitim modellerinde eğitim, teori ve pratiğin iç içe geçtiği, birbirini takip eden ve tamamlayan becerilerin öğretimi biçiminde kurgulanmaktadır. İncelenen yaklaşımlara göre öğrencilerin altyazı 
eğitimi süresince sürekli aktif olması kendi öğrenim deneyimleri aracıllğıyla uzmanlaşmalarının yolunu açacaktır. Öğrencilerin altyazı çevirisi üzerine edindikleri teorik altyapıyı çok sayıda uygulamayla pekiştirmeleri söz konusu becerilerin edinimi açısından son derece önemlidir. Ayrıca sınıf içi uygulamalarda belirli çeviri sorunları üzerine yapılan tartışmalar öğrencilere alana dair çok yönlü bakış açısı kazandıracaktır.

Sonuç olarak altyazı çevirisi eğitiminde türün doğasına uygun eğitim öğretim yaklaşımlarının benimsenmesi gerekmektedir; tasarlanacak eğitimde, öğrenci çeviri türünün temel niteliklerini, türe özgü kısıtları özümsemeli ve öğrendiklerini uygulamaya koyabilmelidir. Öte yandan, gelişen teknoloji günlük yaşam aktivitelerimizi sürekli değiştirmekte ve her yeni gün yeni bir ihtiyacı doğurmaktadır. Teknolojiyle biçimlenen altyazı süreci yeni ihtiyaçlar doğrultusunda sürekli yenilenmektedir. Altyazı çevirisi değişime açık, teknolojiyle beraber dönüşmeye elverişli görsel-işitsel çeviri türlerinden biridir. Bu noktada uygulanacak eğitim yöntemleri sürekli güncellenme ihtiyacındadır. İncelenen altyazı çevirisi eğitim yaklaşımları özellikle teknik açıdan yaşanan gelişmelere paralel bazı uygulama değişiklikleri gerektirebilir. Dolayısıyla, verilecek eğitim yaşanan gelişmeleri takip eden evrilemeye hazır bir yapıda kurgulanmalıdır. Nitekim, altyazı çevirisi eğitimi üzerinde yapılacak her yeni çalışma, mevcut ihtiyaçları sergileyecek, eksik veya geliştirmesi gereken noktaları ortaya çıkaracak ve geleceğin eğitim modellerine ışık tutacaktır.

\section{Kaynakça}

Carroll, Marry (2004). [14.4. 2014]. Subtitling: Changing Standards for New Media. Translationdirectory: www.translationdirectory.com/article422.htm.

Dỉaz Cintas, Jorge \& Remael, Aline (2014). Audiovisual Translation: Subtitling.

Diaz Cintas, Jorge (2008). Teaching and Learning to Subtitle in an Academic Environment. The Didactics of Audiovisual Translation. Amsterdam/Philadelphia: John Benjamins.: 89-104.

Diaz Cintas, Jorge (2008). The Didactics of Audiovisual Translation. Amsterdam/Philadelphia: John Benjamins.

Diaz Cintas, Jorge (2013). The Technology Turn in Subtitling. Translation and Meaning, ed. Marcel Thelen, Barbara Lewandowska-Tomaszczyk. Zuyd University of Applied Sciences: 119-132

Georgakopoulou, Panayota (2006). Subtitling and Globalisation. Jostrans. sayı 6.

Henrik, Gottlieb (2001). Texts, Translation And Subtitling - In Theory, in Denmark: University of Copenhagen.

Karamitroglou, Fotios (1998). A Proposed Set of Subtitling Standards in Europe. Translation journal 2.2

Kruger, Jan Louis (2008). Subtitler Training as Part of a General Training Programme in the Language Professions. The Didactics of Audiovisual Translation. ed. Jorge Diaz Cintas. vol. 77. Amsterdam/Philadelphia: John Benjamins Publishing.

Linde, Zoe de \& Kay, Neil (2016). The Semiotics of Subtitling. London, New York: Routledge.

Nikolić, Kristijan (2015). The Pros and Cons of Using Templates. Audiovisual Translation in a Global Context Mapping an Ever-changing Landscape. Palgrave Macmillan: 192-202.

O'Connell, Eithne (2007). Screen Translation. A Companion to Translation Studies. Clevedon: Multilingual Matters: 123.

Okyayuz Ayşe Şirin, Kaya, Mümtaz (2017). Görsel-Işsitsel Çeviri Eğitimi. Ankara: Siyasal Yayınevi

Okyayuz, Ayşe Şirin (2016). Altyazı Çevirisi. Ankara: Siyasal Yayınevi 
Perez, Luiz. Gonzalez (2008). Audiovisual Translation. Routledge Encyclopedia of Translation Studies. ed. Mona Baker. New York: Routledge: 13-19.

Reiß, Katharina (1971). "Möglichkeiten und Grenzen der Übersetzungskritik.” (1. Auflage). München: Max Hueber Verlag.

Reiß, Katharina (2004). “Type, Kind and Individuality of Text: Decision Making in Translation.” In (içinde) S. Kitron (Trans.), L. Venuti (Ed.), The Translation Studies Reader, pp. 160-171. London: Routledge

Wietrzny, Marta Kajzer, Tymczyńska, Maria. 2015. Devising a Systematic Approach to Examination Marking Criteria for Audiovisual Translation: A Case Study from Poland. The Interpreter and Translator Trainer. Vol 9 Sayı 3. 